\title{
EXPERIENTIAL KNOWLEDGE AND COST IN THE INTERNATIONALIZATION PROCESS
}

\author{
Kent Eriksson \\ Uppsala University
}

Anders Majkgård

Uppsala University

\author{
Jan Johanson \\ Uppsala University 1
}

D. Deo Sharma

Umeå Business School 2

1 Uppsala University, Department of Business Studies, Box 513, S-751 20 Uppsala, Sweden, phone +46 181813 83, fax +46 185553 86, E-mail Jan.Johanson@fek.uu.se

2 Umeå Business School, Department of Business Administration, S-901 87 Umeå, Sweden, phone +46 901664 96, fax +46 901677 64, E-mail Sharma@HH.UMU.SE

The authors would like to thank Professor Dag Sörbom, Department of Statistics, Uppsala University, for his valuable help concerning methodology. 


\title{
EXPERIENTIAL KNOWLEDGE AND COST IN THE INTERNATIONALIZATION PROCESS.
}

\begin{abstract}
Using a behavioral approach, this study identifies and delineates components of experiential knowledge in the internationalization process. Three hypotheses are developed and tested. They center around the lack of knowledge in the areas of foreign business, foreign institutions and firm internationalization, as well as the effect that this lack of knowledge has on the managers' perceived cost in the internationalization process. With the help of a LISREL-based structural model, the three hypotheses are tested on a sample of 362 service firms. The analysis shows that lack of internationalization knowledge has a strong impact on the lack of both business and institutional knowledge which, in turn, influence the perceived cost in internationalization. But there is no direct effect of lack of internationalization knowledge on perceived cost in internationalization.
\end{abstract}




\section{INTRODUCTION}

In furthering our understanding of the dynamics of the internationalization of firms, process models have played a significant role [Bilkey and Tesar 1977; Cavusgil 1980, 1984; Czinkota 1982; Johanson and Vahlne 1977, 1990; Luostarinen 1980; Reid 1983]. In these models, market-specific experiential knowledge is central in explaining the firm's internationalization process. A vast amount of research, using the concept of experiential knowledge, on the internationalization process and the choice of mode for entering foreign markets has been accumulated [Barkema et al. 1996; Beamish 1990; Calof and Beamish 1995; Erramilli 1990, 1991; Erramilli and Rao 1990, 1993; Hirsch 1993; Kogut and Singh 1988; O’Grady and Lane 1996; Reid 1984; Root 1987; Sharma and Johanson 1987; Wiedersheim-Paul et al. 1978] Surprisingly, none of the above-mentioned work has explicitly dealt with the cost in internationalization process. This is surprising since the management of internationalization unavoidably gives rise to the question of cost [Carlson 1974]. An internationalization process entails risk and the investment of resources. Here the issue of the effects of the critical experiential knowledge on the cost in the internationalization process becomes important. Cost aspects have a bearing on the profit generated by firms [Bilkey 1982], on a firm's inclination to enter foreign markets [Dichtl et al. 1990], and on the selection or changing of foreign market entry mode [Calof and Beamish 1995].

In international business research of other traditions, the cost of international operations has been discussed. In the eclectic approach, for example, internationalization is seen as resulting from three factors: namely, firm-specific advantage, country-specific advantage, and internalization advantage [Dunning 1977, 1980, 1988]. According to this paradigm, in the absence of market imperfections, firms would rely on export as the only foreign market entry mode [Calvet 1981; Hymer 1976]. In the real world of market imperfections caused by government-imposed restrictions [Kindleberger 1969] and knowledge [Rugman 1981], however, firms can choose between a variety of foreign market entry modes, e.g., wholly- 
owned subsidiaries, joint ventures, licensing, and other contractual agreements. The joint influences of the three factors on the selection of foreign market entry is investigated by Aggarwal and Ramaswami [1992]. In the models based on the transaction cost approach [Williamson 1975], cost factors are critical in explaining a firm's international operations [Anderson and Gatignon 1986; Beamish and Banks 1987; Gatignon and Anderson 1988]. The same holds true for internalization theory [Buckley and Casson 1976]. Neither eclectic theory nor the transaction cost approach elucidate the process of internationalization or, consequently, the cost in this process. Common to these approaches, is their assumption that each foreign market entry is made in isolation [Hill et al. 1990; Kim and Hwang 1992].

What is the cost consequences of lack of experiential knowledge in the course of the internationalization process? Since the behavioral models of the internationalization process stress the role of perceived problems and opportunities in the internationalization of a firm, this paper pays special attention to the perceived cost associated with internationalization. The models assume that managers act on the basis of their cost perceptions and that those perceptions are based on past experience [Johanson and Vahlne 1977]. Accordingly, the purpose here is to identify and delineate the principal components of experiential knowledge that influence management's perception of the cost in internationalization. The main constituents of experiential knowledge, and the links between them and the cost of internationalization in service industry firms, are investigated. The perceived cost may concern not only the direct cost of starting up business abroad, in the form of traveling costs, salaries, collecting foreign market information, purchase or hire of office space, etc., but also the costs due to changes in the organizational set-up of the firm, such as training and retraining of staff, and changes in routines, reporting systems and procedures. In addition, opportunity costs for seeking and evaluating local partners may also be included in the case of joint ventures or other alliances abroad. This paper is, however, not concerned with operationalizing or measuring the individual cost components. 
Since the internationalization process models are based on the experience of manufacturing firms, most empirical studies of internationalization also concern such firms. Most of the studies on service industries supply limited insight into the internationalization process of service firms [Lo and Yung 1988; Weinstein 1974, 1977]. A secondary purpose of this paper is thus to apply the experience-based internationalization process models to firms in the service industry and suggest possible extensions. At the same time, the study tests the validity of the role of experiential knowledge in the model.

The study differs from previous research in the methodology used. In previous research, experience, as indicated by age or number of countries entered by firms, has been used to explain the pattern of internationalization observed [Erramilli 1991; Johanson and Wiedersheim-Paul 1975; Yu 1990]. This study goes beyond that explanation and introduces perceived cost as a mediating variable and formulates a structural model of the influence of a number of aspects of experiential knowledge on perceived cost of an incremental step in the internationalization of the firm. Moreover, while most other studies focus on entry mode as the incremental step, this paper, in the spirit of the process model, attempts to capture a more general incremental step by considering additional commitments to foreign customers. In this way, our approach falls more in line with the basic assertions of the internationalization process model.

We begin with a discussion of the internationalization process. This leads to three hypotheses on the perceived cost in the internationalization process. The hypotheses focus on the role of experiential knowledge in this process. Following a presentation of the method and data employed, the empirical analysis is conducted in two steps: construct analysis and structural model analysis. The results are then discussed and some implications examined. 


\section{THE INTERNATIONALIZATION PROCESS OF FIRMS}

In a review of internationalization process models Andersen [1993] distinguishes between a U-model (Uppsala) by Johanson and Vahlne [1977] and the I-models (Innovation) by Bilkey and Tesar [1977], Cavusgil [1980, 1984], Czinkota [1982] and Reid [1983]. This paper is based on the U-model developed by Johanson and Vahlne [1977]. The main reason is that the U-model is assumed to be valid for firms of any size while the I-models may be applied to small firms only [Andersen 1993]. The models are similar, however, in that they are behavioral in nature and in that experiential knowledge is a prominent factor in the internationalization process.

The behavioral model of internationalization is based on the theory of the growth of the firm [Penrose 1959] and the behavioral theory of the firm [Aharoni 1966; Cyert and March 1963], and asserts that the internationalization of a firm is an incremental process [Johanson and Vahlne 1977]. The model rests on the assumption that firms have imperfect access to information and explains internationalization as a process of increasing experiential knowledge. It postulates an unpredictable incremental interplay between market commitment and market knowledge development. It also posits that experiential knowledge of the market, the clients, the problems and the opportunities abroad are acquired by operating in the international market. Experiential knowledge not only yields a reduction of the risks involved in going abroad, but also provides a vehicle for acquiring knowledge of internal and external resources and of opportunities for combining them.

The model identifies state and change aspects. The state aspects consist of market knowledge and market commitment. The market commitment concept is composed of two factors: the amount of resources committed to a market and the degree of that commitment. The degree of commitment refers to the ease with which resources can be moved from one market to another. Knowledge is divided into objective knowledge and experiential knowledge [cf. Penrose 1959]. Objective knowledge is acquired through standardized methods of collecting 
and transmitting information, i.e. market research, and can easily be transferred to other countries and replicated by other firms. A critical assumption of the model by Johanson and Vahlne [1977], supported by Ayal and Zif [1979], Denis and Depelteau [1985], Reid [1984], Simpson [1974], and Sunzook [1978], is that objective knowledge is of minor importance in a firm's internationalization process. The remainder of this paper focuses on experiential knowledge, which is viewed as a driving force in the internationalization process [Johanson and Vahlne 1977]. Experiential knowledge is country-specific and cannot be transferred between firms or business units. Accumulating experiential knowledge is costly. These costs arise because collection, transmission and interpretation are all based on specific situations [Carlson 1974]. Current activities, part of the change aspect, are the primary source of experiential knowledge. The other change aspect is the decision to commit resources. Decisions are made when problems and opportunities arise. Firms apply the solutions which have been successfully applied in the past [Cyert and March 1963].

In the internationalization model, two dimensions of international expansion are identified: psychic distance and establishment chain. The model postulates that as the psychic distance between markets increases, the more difficult it becomes for firms to collect and interpret incoming information properly. The firm's experiential knowledge derived from the domestic market is of limited value in markets located at a great psychic distance. The psychic distance between the home and foreign markets affects market selection as well as choice of entry mode. Firms with little experience of foreign markets prefer those which are similar to their own domestic market and which are not located at too great a psychic distance. As firms accumulate experiential knowledge, the influence of this kind of distance on the choice of entry mode decreases. In their study of Swedish manufacturing firms, Hörnell, Vahlne and Wiedersheim-Paul [1972] found that the firms first entered markets at a short psychic distance and later went into more distant markets. This study was replicated by Nordström [1990] who reported almost the same establishment pattern. Among US-based firms, Vernon [1966], and Kogut and Singh [1988] report a steady shift from culturally familiar to culturally 
less familiar markets. Firms with vast stocks of experience show less preference for similar markets. Davidson [1983] reports that US-based firms first prefer to enter English-speaking countries. Studies of service firms in this context are few. Two studies from the US, Weinstein [1977], and Erramilli and Rao [1993], find that such firms start their internationalization with countries at a short psychic distance.

In each country the firm increases its commitment incrementally as it learns about the market, the model postulates. This is manifested in a sequence of operational forms labeled the establishment chain. First the firm exports, then a marketing subsidiary is established, followed by foreign production. Johanson and Wiedersheim-Paul [1975] noted such a pattern among Swedish manufacturing firms. Davidson [1980], Franko [1989] and Gatignon and Anderson [1988] have observed an increasing propensity to select wholly-owned subsidiaries as experiential knowledge increases. Davidson [1980], Goodnow and Hansz [1972], and Kogut and Singh [1988] show that, among American companies, the usage of joint ventures increases with sociocultural distance from the domestic market. Similar results are reported by Gatignon and Anderson [1988], Green and Cunningham [1975], and Stopford and Wells [1972]. Calof and Beamish [1995] report rather mixed findings, but on the whole results in line with the above presentation.

Some confusion does, however, exist. Maclayton et al. [1980] found no significant correlation between a firm's experience in foreign markets and its evaluation of individual markets. Daniels et al. [1976] and Shetty [1979] reported a shift toward licensing and joint ventures as a firm's experiential knowledge grew. Davidson and McFetridge [1985] and Hedlund and Kverneland [1985] showed a decrease in the reliance on wholly-owned subsidiaries as foreign experience increases. Bureau of Industry Economics [1984], Millington and Bayliss [1990], and Newbould et al. [1978] published similar findings. Stopford and Wells [1972], studied US investments in Europe, concluding that almost threequarters of initial ventures used wholly-owned subsidiaries. In general, these researchers have 
studied only the early stages of foreign market entry [Erramilli 1991]. In light of these findings, Erramilli [1991] postulates a U-shaped relationship between experiential knowledge and a firm's propensity to rely on high-control modes of entry into foreign markets. O’Grady and Lane [1996] demonstrate that entering a foreign market near the domestic market may result in poor performance. On the whole, current research supports the view that, in the internationalization process, experience is important in the selection of entry mode.

\section{THE COST OF LACK OF EXPERIENTIAL KNOWLEDGE IN THE INTERNATIONALIZATION PROCESS: THREE HYPOTHESES}

On the basis of the literature on the internationalization process of firms reviewed above, three hypotheses can now be developed and specified.

Firms start their operations in domestic markets. Initially, firms develop routines and administrative structures to manage domestic market operations. The routines and administrative structures thus developed are not sensitive to the signals flowing from the overseas markets. As firms operate abroad, they accumulate experiential knowledge and change their routines and administrative structures. This process is gradual. The internationalization process model explicitly emphasizes that the internationalization of a firm entails the commitment of exchange-specific and market-specific resources. These exchange-specific commitments are triggered when firms acquire experiential knowledge of a particular market [Bilkey and Tesar 1977; Bureau of Industry Economics 1984; Millington and Bayliss 1990; Newbould et al. 1978]. Indeed, in their original model, Johanson and Vahlne [1977] explicitly postulate a positive relation between experiential knowledge of a market and the level and speed of resource commitment in that market. This relation is due to a greater ability to detect the opportunities and reduce the uncertainties of going abroad. These market-specific resource investments can take the form of human resources, technology or know-how. Resources are by definition valuable and are costly to obtain. 
Increasing experiential knowledge triggers greater resource commitment to a particular market. The experience-seeking firm must engage in foreign operations. This implies a presence abroad, exposure to the situation abroad, and interaction with specific customers, intermediaries and other firms in the international market. Acquiring local experiential knowledge is time-consuming and important for performance as demonstrated by a study of Japanese ventures in Asia [Makino and Delios 1996].

A critical consideration in internationalization, is the compatibility between a firm's existing resources and those needed in a particular foreign market. Knowledge is required both about the market and the firm [Johanson and Vahlne 1977; Madhok 1996, 1997]. Thus, there is a need for experiential knowledge of the firm's capability and resources to engage in international operations, which we label "internationalization knowledge“, and knowledge of the foreign markets in which the firm is going to operate [Yu 1990]. Experiential market knowledge pertains to two different aspects: business knowledge and institutional knowledge. By "foreign business knowledge“" we mean experiential knowledge of clients, the market, and competitors. "Foreign institutional knowledge" refers to experiential knowledge of government, institutional framework, rules, norms and values.

A lack of experiential knowledge on a particular client's way of working, his organization and decision-making, and its particular needs regarding goods and services, is problematic for an internationalizing firm. All this calls for the cultivation of business contacts to acquire a first-hand feel for the preferences, practices and customs in the market [Denis and Depelteau 1985; Reid 1984]. A local presence, e.g. a subsidiary, allows the internationalizing firm to gain more differentiated knowledge of the clients and the local business. Likewise, it enables the internationalizing firm to accumulate the kind of information it really needs, and to interpret the information in a firm-specific context [Carlson 1974]. With increasing experiential knowledge of the clients, the market and the demand situation, firms become more able to perceive opportunities in foreign markets, thereby reducing uncertainty [Kogut 
and Singh 1988]. Firms with experiential knowledge develop a position in a particular market, and their engagement in that specific market gradually increases. Thus, Davidson [1980, 1983] and Franko [1989] noted that having a production base in a foreign market has a positive impact on the subsequent penetration of that market. As discussed above, there are some empirical results that contradict this, but generally speaking, it can be said that experiential knowledge does influence a firm's internationalization process.

The extent to which a firm's current experiential business knowledge may be used in the internationalization process may vary. Firms that elicit the assistance of their current exchange relationships in internationalization, have access to the experiential knowledge required for this internationalization. These firms have already committed client-specific resources to facilitating exchange [Dunning and McQueen 1983; Jones 1981; Sagari 1992; Seymour 1986; UNCTC 1981; Walter 1985]. Few extra resources have to be invested in seeking experiential knowledge [Erramilli and Rao 1990; Sharma and Johanson 1987]. These firms have already incurred costs that may be attributed to the internationalization process. Other firms must internationalize on their own and spend resources on detecting and exploiting the business opportunities in the international market. They lack experience of new markets abroad and of specific foreign clients, and must acquire experiential knowledge of the international market. This is costly. And depending upon the level of the firm's experiential business knowledge, the cost in the internationalization process will vary.

H 1: The greater a firm's lack of foreign business knowledge, the higher the perceived cost in the internationalization process.

As we have noted, the internationalization model rests on the assumption of imperfect knowledge on the part of the decision-makers in the internationalization process. This lack of knowledge concerns the institutions to be found in foreign markets, foreign governments and bureaucracies and the ways in which these work. A lack of experiential institutional knowledge is problematic, as it is difficult for the company to acquire an adequate 
understanding of the technical and commercial laws and norms that apply in a foreign market. It is not only important to know what the statute-books say, but also how that is applied in practice at a particular time by a particular government agency. It may be a question of the import and export of goods and services, tariffs, local taxes, general conditions in the market, as well as related problems and prospects. Knowledge of these institutional matters is a source of advantage [Jansson et al. 1995; Lenway and Murtha 1994; Murtha and Lenway 1994; Stopford and Strange 1991; Yoffie 1988]. The same is true of knowledge of the language [Dichtl et al. 1990] and of the local culture [Hofstede 1984a, 1984b], both of which facilitate becoming acquainted with local needs and requirements. A knowledge of local institutional norms and laws reduces the cost in internationalization.

H 2: The greater a firm's lack of foreign institutional knowledge, the higher the perceived cost in the internationalization process.

But the experiential cost of the internationalization process is not only related to knowledge of foreign business and institutions, it is also a matter of learning how to organize and manage internationalization efforts [Ball and Tschoegl 1982; Terpstra and Yu 1988]. Organizational routines, procedures and structures matter, and are decisive in controlling behavior in organizations [Cyert and March 1963; March and Simon 1958]. They make up an organization's knowledge assets, are accumulated over time, and constitute conditions for subsequent behavior. Internationalization is no different. Organizational routines are, however, opaque [Kilduff 1992, 1993; Nelson and Winter 1982; Polanyi 1962] and decisionmakers' knowledge on these routines is imperfect. This, as pointed out by Winter [1987], is because decision-makers in a firm are the "symbol processing brains" of the organizations. A great part of organizational routines operate outside the formal hierarchy and structure of a firm [Kilduff 1993]. Moreover, as routines outlast individuals, decision-makers lack a complete knowledge of organizational routines. A firm must consider new situations and problems that arise in connection with international business initiatives and how they affect 
the existing resources and routines of the firm [Madhok 1997]. When entering a foreign market, experiential knowledge about international business is gained and stored in the firm's routines and programs [Nelson and Winter 1982]. This accumulated experiential knowledge then exerts an influence on the future internationalization of the firm through its influence on information search processes, e.g., what type of information is sought, and where. It also affects the firms' ability to evaluate international initiatives. It can be expected that the less experience a firm has of international business, the less knowledge it will have on how to organize international operations [Madhok 1996] The perceived cost of further internationalization will therefor be greater [Yu 1990]. Accumulated experience in internationalization is neither specific to a country nor to a mode of entry. It is firm-specific and constitutes a particular firm's "way of going international“. A firm’s experience of organizing internationalization, experiential internationalization knowledge, means knowing what knowledge is required in different situations and different settings connected with internationalization, and where to seek this knowledge.

H 3: The greater a firm's lack of internationalization knowledge, the higher the perceived cost in the internationalization process.

The three hypotheses are combined in a structural model, with perceived cost in the internationalization process as a dependent variable. The model is tested empirically on a sample of service firms.

As mentioned at the outset of the paper, there is reason to discuss whether the arguments presented in the previous pages apply to firms in both the manufacturing and the service sectors. The question is somewhat controversial. On the one hand, there are researchers [Grönroos 1990; Lovelock 1988; Normann 1984] who argue that service firms differ in nature from manufacturing companies. Others [Buckley et al. 1992; Erramilli 1991; Levitt 1972; Quinn and Gatignon 1986; Sauvant and Mallampally 1993] claim that these differences are differences of degree, not of nature. Although we cannot hope to resolve this controversy 
in a study based on service firms alone, we can take a step towards resolving it by comparing firms in which the services are product-related and firms offering pure services. There is reason to expect that the need for experiential knowledge in the internationalization of a firm may vary depending upon the type of industry in which the firm is active. In more productrelated industries, a firm may benefit more from experiential knowledge of the product and of its functioning. As the service content of a firm's offer increases, market-related experiential knowledge becomes more important. Consequently, we have reason to investigate the differences between these two types of industry as regards the experiential cost in the internationalization process.

\section{EMPIRICAL METHOD}

The general incremental character of the internationalization process, wherever or whenever it occurs, is a fundamental assumption of the process model. Obviously, it is difficult to operationalize this process in a standardized research design. In order to capture it, however, the study is designed to focus on an incremental internationalization commitment. Respondents in eight different service industries were asked questions related to their lack of the three kinds of knowledge and about the perceived cost associated with an incremental market commitment. In order to get a measure that did not relate to any specific internationalization decision, incremental market commitment has been measured as the execution of an additional client order abroad. The term "additional“ implies receiving a new assignment from customers. This includes situations where a firm is going abroad for the first time or where a firm that is already operating abroad executes an additional assignment abroad. The firm may provide the service abroad without moving abroad. The respondents were not asked to consider any specific market. This made it possible to analyze the general effect of the knowledge factors on the perceived cost in the internationalization process. 
On the basis of information from personal interviews, a questionnaire-based statistical survey was conducted. We systematically searched for Swedish service firms engaged in international operations. The Central Statistical Bureau in Sweden did not have data on the international operations of the Swedish service firms. Therefore, we searched for information from three secondary sources; trade registers, branch registers and business publications. ${ }^{1} \mathrm{We}$ also conducted some 70 face-to-face interviews with CEOs of Swedish service firms. During these interviews, we requested the respondents to supply the names of other firms in their branch that were doing business abroad. As Table 1 shows, there is a higher representation of firms in engineering, architecture, and management consulting.

\section{Put Table 1 here}

Altogether 774 companies were included in the mail survey. The questionnaires were addressed to the presidents of these companies, who were deemed most likely to be involved in the internationalization decision process of their firms. The information was supplied by executives actually engaged in foreign operations of the firm. They are presidents (329 cases), and vice president foreign operations, vice president finance and others (33 cases). A five-point Likert scale (ranging from "not at all important" to "very important") was used.

73 questionnaires were returned undelivered and 49 companies expressed regret at their inability to participate for various reasons, the most common of which was their no longer being engaged in international business. Of the remaining 652 potential respondents, usable answers were submitted by 409 . The response rate of $62.7 \%$ compares favorably with rates reported in other surveys involving service firms [e.g. Erramilli 1991; Zeithaml et al. 1985]. An additional 47 of the 409 were dropped from the analysis for having insufficient information on a number of variables. The remaining 362 firms provided data on all the key variables. 
Among the respondent firms, 34 went abroad during the 1960s or earlier. 171 firms carried out their first assignment abroad in 1980 and later. One firm, VBB, carried out their first foreign operation as early as 1902. 152 firms had 1-10 employees, and 68 firms had 100 or more employees.

A standard test of non-response bias was conducted. Early respondents were compared to late respondents, with late respondents being assumed to be similar to non-respondents [Armstrong and Overton 1977]. Accordingly, the sample was split into two categories on the basis of survey return dates, with the first $65 \%$ classified as early and the last $35 \%$ as late respondents. They were viewed as representative of actual non-respondents. We found no significant differences between these two groups on variables such as number of employees, total turnover and industry distribution. Non-response bias is thus not a problem.

\section{LISREL}

The hypothesized causal relations were investigated by LISREL, which is a structural equation modeling method. On the recommendation of Jöreskog and Sörbom [1993], we used LISREL for explorative purposes as well as hypothesis-testing. A structural model with LISREL has two components. The first is a set of indicators related to a higher order variable, which represents latent, common properties of the indicators. The second is the definition of causal relations between the latent variables in a structural model. In technical terms, LISREL derives causal structures by analyzing both error covariances and regular correlations [Bollen 1989; Bollen and Long 1993; Hayduk 1987; Jöreskog and Sörbom 1993].

The confirmatory analysis is performed in two steps, the first step of which investigates whether the indicators are valid measures of the theoretically deduced constructs. For this purpose, the indicators are grouped according to theoretical assumption. In the second step, 
the causal relations between the constructs are analyzed according to the hypothesized structural model.

The validity of LISREL models is estimated by the validity of the entire model (nomological validity), and also by the extent of separation between constructs (discriminant validity) and the homogeneity of constructs (convergent validity). The overall fit of the LISREL models is assessed by Error! Reference source not found. ${ }^{2}$ and degree of freedom measures and a probability estimate (p-value) [Jöreskog and Sörbom 1993:121]. The Error! Reference source not found. ${ }^{2}$ and degree of freedom, together, measure the distance between data and model, and the p-value is a significance estimate. Together these constitute our measure of nomological validity. Discriminant and convergent validity are judged by studying the tvalues and $\mathrm{R}^{2}$-values of each relation in the model. The $\mathrm{R}^{2}$-value is a measure of the strength of a linear relationship estimate [Jöreskog and Sörbom 1993:121]. As a test of significance, the t-values are studied [Jöreskog and Sörbom 1993:108]. The results of the validity of our constructs are shown in Table 2.

Pairwise deletion is used to account for missing values. The total number of missing values ranges from 35 to 106, depending on the item (see Appendix). We have also tested the results by listwise deletion and received more or less the same result.

\section{CONSTRUCT ANALYSIS}

The construct "lack of business knowledge" is meant to capture the lack of business knowledge about competitors, clients and markets abroad. The construct consists of two indicators (Table 2). The two indicators reflect two important ways of gaining foreign business knowledge. They concern the respondents' evaluation of the lack of foreign subsidiaries or representative companies abroad, or the lack of cooperative agreements. These may include agreements with agents and alliance partners. The t-values are 16.32 and higher, and the $\mathrm{R}^{2}$-values are above 0.68 , suggesting good convergent validity for the constructs. 


\section{Put Table 2 here}

The construct "lack of institutional knowledge" reflects knowledge about the institutional conditions of foreign markets. The construct consists of two indicators. They concern a lack of knowledge about the language, laws, norms and standards in foreign markets. That both indicators constitute a latent variable is validated by t-values above 14.42 , and $\mathrm{R}^{2}$-values above 0.56 .

The construct "lack of internationalization knowledge" represents the accumulated internationalization experience gained by a firm in its international operations. The construct consists of two indicators. The first is the respondent's evaluation of the importance of a lack of experience in doing business abroad. The second is a lack of unique knowledge and/or competence. The construct is valid, t-values are above 13.87 and the $\mathrm{R}^{2}$-values are above 0.49 .

The construct "perceived cost" consists of one indicator based on the perception of the overall cost of executing an additional client order abroad. This single indicator is assumed to capture the overall cost judgments made by managers.

To assess discriminant validity, a model with no causal relations between constructs (measurement model) is created. Our set of constructs are discriminantly valid. Key statistical estimates show that no pair of constructs are unidimensional. 


\section{STRUCTURAL MODEL ANALYSIS}

The second step of the empirical investigation is to test the model of causal relations hypothesized. Figure 1 depicts the model of relations between institutional knowledge, business knowledge, internationalization knowledge and cost. The model's key statistical measures are acceptable, since Error! Reference source not found. ${ }^{2}=16.76$ (9) and p = 0.053. T-values are 1.96 and higher, and $\mathrm{R}^{2}$-values are 0.21 and higher, except for internationalization knowledge whose relation to perceived cost is insignificant. Lack of institutional (0.19) and business (0.26) knowledge both lead to higher perceived costs.

\section{Put Figure 1 here}

The insignificant relation between internationalization knowledge and perceived cost provides some clues to a further elaboration of the model. In the discussion of the hypotheses, the need for compatibility between knowledge about the firm's resources and knowledge about the market is stressed. According to this view, it is not possible to articulate the need for market knowledge without knowing the specific resources of the firm. This suggests that there is reason to expect causal relations from lack of internationalization knowledge to lack of both business knowledge and institutional knowledge. Such a structural model is depicted in Figure 2. The model's key statistical estimates are good since Error! Reference source not found. ${ }^{2}=19.37(11)$ and $\mathrm{p}=0.055$. All t-values are 3.09 or higher and the lowest $\mathrm{R}^{2}$ is 0.22. The statistics of this model (Figure 2) are better than those of the previous model (Figure 1).

Put Figure 2 here 
The analysis shows that causal relations between internationalization knowledge on the one hand, and business and institutional knowledge on the other, are strong. Both business knowledge and institutional knowledge, in turn, influence the perceived cost of internationalization. There is no direct relation, however, between internationalization knowledge and perceived cost. Internationalization knowledge operates only via the more specific constructs of business and institutional knowledge. The LISREL estimates show, however, that the indirect effects of lack of internationalization knowledge on perceived cost are $0.36, t=7.87$. The magnitude of the cost associated with collecting business knowledge and institutional knowledge in the internationalization process is fairly equal, i.e. managers perceive that it costs as much to gather business knowledge as it does to gather institutional knowledge.

In order to test the validity of the analysis, the sample was divided into two groups, one in which the tangible elements in the services sold are more readily identified such as productrelated businesses, like computer software, engineering and architecture firms $(\mathrm{n}=100$, $33 \%$ ), and one, in which the tangible elements in the service provided are less readily identified such as non-product-related firms dealing in management consulting, education, accounting, advertising and legal service $(n=207,67 \%)$. The analysis shows the groups to be identical (Error! Reference source not found. ${ }^{2}=50.08(39), p=0.11$ ).

As a further test of the model, the sample was divided in large and small firms. It is sometimes assumed that firm large size is associated with more experience than small size. With the limit set at 20 employees, the number of small firms is 158 (62\%), and of large firms 95 (38\%). The group analysis shows that the causal structure is valid in both groups after three modifications (Error! Reference source not found. ${ }^{2}=50.05(36), p=0.06$ ). The modifications show that the magnitude of indicator loadings vary between groups. The structural model is valid for both large and small firms. 
Since several of the empirical studies of the internationalization process use time of international operations as a proxy for experience (Erramilli 1991) we also divided the sample into firms with short and long prior international operations. The group of firms with less than three years of international experience is 91 (36\%), and the group with more than three years are 162 (64\%). Results show that the causal structure is valid in both groups after one modification $\left(\mathrm{Chi}^{2}=53.17(38), \mathrm{p}=0.05\right)$. This third test of the robustness of the cost model demonstrates that the model is valid irrespective of time of international operations.

Altogether, the three group analyses provide a strong test of the general validity of the causal structure linking the experiential knowledge components to each other and to perceived cost in the internationalization process.

\section{DISCUSSION AND CONCLUDING REMARKS}

In contrast to earlier empirical research on internationalization of firms, this study addresses the effect of experiential knowledge on the cost of the internationalization process. Our results confirm that there is a cost tag associated with experiential knowledge in the internationalization of a firm. The analysis shows that in the process of internationalizing, firms have to seek experiential knowledge on individual clients and markets, as well as on institutional factors such as local laws, local governments and local cultures. This information is collected through activities abroad and through a presence in foreign markets. Activities and presence abroad entail costs. These costs are related to collecting, encoding, transferring and decoding knowledge, as well as changing the resource structures, processes, and routines in the organization.

The analysis also shows that a firm's experience of the internationalization process influences the perceived cost in this process. This implies that some experiential knowledge is located in the firm, in its decision-making routines and structures. Johanson and Vahlne [1977] suggest that the relevant experience of a firm concerns specific markets. Our findings indicate, 
however, that accumulated internationalization experience that affects both business knowledge and institutional knowledge, is not related to specific country markets. It is a firmspecific experience relevant to all markets. But firm-specific internationalization knowledge affects the perceived cost in internationalization only indirectly, through experiential market knowledge. It seems reasonable to regard it as a kind of procedural knowledge concerning, for instance, what kind of knowledge a firm needs in different situations. This finding may explain the results obtained by Erramilli [1991], that scope, measured in terms of the number of countries in which the firm has entered in the past, explains the choice of entry mode into a new foreign market. More differentiated research on the nature of this knowledge and how it is accumulated and transferred from one country to another is needed.

Rather than being conclusive, the findings of this study open new avenues for further research. Both modeling and measurement can be developed. There are other samples to be investigated and other measures to be used. In future research, constructs such as managers "perception of costs" should, for example, be measured in a more sophisticated manner. The study has, however, indicated a possible fruitful approach to further study of internationalization processes. Such an approach implies a focus on the perceptions and cognitive structures of managers who enact and have personal experience of the internationalization of firms. As shown by this study, LISREL analysis of structural models can be a powerful tool in enhancing our understanding of internationalization processes.

The findings of the study also have managerial implications. First, the view that internationalization is a matter of learning is supported. But it is not only a matter of learning about foreign markets and institutions. Knowledge must also be gained on the internal resources of a firm, and what the firm is capable of when exposed to new and unfamiliar conditions. The results suggest that, in internationalizing, a firm must develop structures and routines that are compatible with its internal resources and competence, and that can guide the search for experiential knowledge about foreign markets and institutions. On a different 
level, this can be viewed as the need to develop a cognitive framework showing what further knowledge about foreign markets is relevant.

Our results show that Swedish managers feel that a deficiency in knowledge of language is a problem in the internationalization process of firms. In this respect our findings are different from those of Beamish and Calof [1989].

One critical issue of this paper is the perceptions of the firms involved in internationalization. How do these perceptions relate to the real situation? This is important for the internationalizing firm. Managerial perceptions guide decision-making, whose outcome, in time, will reveal the success or failure of these decisions and the accuracy of the cost perceptions [O'Grady and Lane 1996]. The outcomes are real and form the platform for experiential knowledge. Success and failure teaches a firm what course of action is suitable in a specific international setting. In fact, there is reason to expect that internationalization decisions based on inaccurate cost perceptions will have a stronger impact on experiential learning than those based on accurate perceptions. Outcome-based knowledge is invested in the organizational routines and processes, and there is reason to assume that many small mistakes in gradual internationalization allows management to form more realistic perceptions than does a single great mistake in a leap-frogging approach to internationalization. This should, however, be investigated empirically.

Moreover, this demonstrates that internationalization is a process that is difficult to plan in advance. The structures and routines mentioned above cannot be established beforehand, but must be built gradually as a consequence of learning both what a firm is capable of and what a foreign market needs. In this process, understanding the history of the firm is crucial. The planning of internationalization efforts must allow for considerable adjustment, use of slack resources and restructuring. 
The paper indicates the importance of three roads to experiential knowledge: local presence, repetition and variation. We argue that experiential knowledge of foreign markets requires durable and repetitive interactions abroad. Sporadic interaction with market actors abroad produces little experience. Variation, i.e. presence of an internationalizing firm in a variety of foreign markets, will enrich the organizational routines and procedures in the firm. This will also improve information-searching and interpreting capabilities of the firm. Attention to these aspects is critical to a firm’s efforts to internationalize operations. 


\section{NOTES}

1. The following sources were used Advokatsamfundets matrikel, Affärsvärlden, Dagens Industri, Företagskatalogen, Konsultguiden, Tekniska Konsultguiden, The Association of Public Relations Consultancies in Sweden and Veckans Affärer. 
APPENDIX

\section{Correlation Matrix}

\begin{tabular}{|c|c|c|c|c|c|c|c|}
\hline \multicolumn{8}{|l|}{ Sample size $=362$} \\
\hline & 1 & 2 & 3 & 4 & 5 & 6 & 7 \\
\hline 1. COST & 1.00 & & & & & & \\
\hline 2. LANGUAGE & 0.29 & 1.00 & & & & & \\
\hline 3. INSTITUTE & 0.30 & 0.60 & 1.00 & & & & \\
\hline 4. SUB & 0.36 & 0.25 & 0.34 & 1.00 & & & \\
\hline 5. COOP & 0.34 & 0.35 & 0.35 & 0.71 & 1.00 & & \\
\hline 6. FOREXP & 0.35 & 0.51 & 0.54 & 0.46 & 0.48 & 1.00 & \\
\hline 7. UNIQCOM & 0.27 & 0.40 & 0.37 & 0.32 & 0.40 & 0.65 & 1.00 \\
\hline Mean: & 2.70 & 2.78 & 2.84 & 2.35 & 2.40 & 2.90 & 2.64 \\
\hline Standard deviation: & 1.15 & 1.26 & 1.12 & 1.29 & 1.24 & 1.25 & 1.32 \\
\hline Missing values: & 36 & 37 & 38 & 103 & 106 & 39 & 35 \\
\hline
\end{tabular}

The managers were asked the following questions.

How important are the following factors as obstacles for the possibilities of your firm to acquire assignments from abroad?

1. High costs

2. Lack of language knowledge

3. Lack of knowledge of foreign laws/norms/standards

4. Lack of subsidiaries/branches outside Sweden

5. Lack of cooperative agreements with foreign firms

6. Lack of foreign experience

7. Lack of unique knowledge/competence 
TABLE 1

Sample Size by Industry

\begin{tabular}{lrr}
\hline Service Industry & $\mathbf{n}$ & $\mathbf{\%}$ \\
\hline Legal & 16 & 4.5 \\
Engineering and architecture & 119 & 32.9 \\
Computer software and data processing & 36 & 9.9 \\
Advertising & 54 & 14.9 \\
Accounting & 17 & 4.7 \\
Education & 19 & 5.2 \\
Management consulting & 78 & 21.5 \\
Miscellaneous services (maintenance, leasing, etc.) & 23 & 6.4 \\
\hline Total & 362 & 100
\end{tabular}


TABLE 2

The Constructs and their Indicators

\begin{tabular}{lllll}
\hline Constructs & Indicators & $\boldsymbol{\lambda}$ & $\mathbf{R}^{\mathbf{2}}$ & $\mathbf{t}$ \\
\hline $\begin{array}{l}\text { Lack of business } \\
\text { knowledge }\end{array}$ & $\begin{array}{l}\text { Lack of cooperative } \\
\text { agreements (COOP) }\end{array}$ & 0.86 & 0.75 & 17.22 \\
$\begin{array}{l}\text { Lack of subsidiary } \\
\text { (SUB) }\end{array}$ & 0.82 & 0.68 & 16.32 \\
$\begin{array}{l}\text { Lack of institut- } \\
\text { ional knowledge }\end{array}$ & $\begin{array}{l}\text { Lack of knowledge about } \\
\text { foreign laws/norms/ } \\
\text { standards (INSTITUTE) }\end{array}$ & 0.79 & 0.63 & 15.21 \\
$\begin{array}{l}\text { Lack of foreign language } \\
\text { (LANGUAGE) }\end{array}$ & 0.75 & 0.56 & 14.42 \\
$\begin{array}{l}\text { Lack of internat- } \\
\text { ionalization } \\
\text { knowledge }\end{array}$ & $\begin{array}{l}\text { Lack of foreign experience } \\
\text { (FOREXP) }\end{array}$ & 0.93 & 0.87 & 19.12 \\
$\begin{array}{l}\text { Lack of unique knowledge/ } \\
\text { competence (UNIQCOM) }\end{array}$ & 0.70 & 0.49 & 13.87 \\
\hline $\begin{array}{l}\text { Perceived cost } \\
\text { Perceived cost of an } \\
\text { additional assignment } \\
\text { abroad (COST) }\end{array}$ & 1.00 & & 1.00 \\
\hline
\end{tabular}


FIGURE 1

Model of Hypothesized Causal Relations

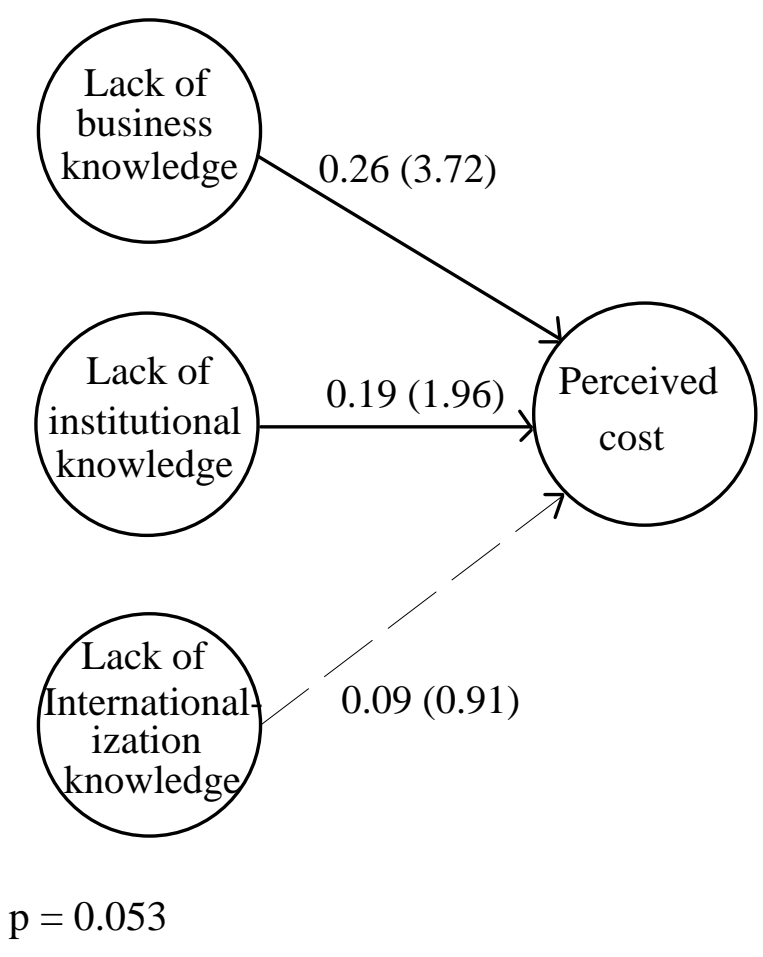

Note: The figures given are factor loadings of causal relations with t-values in parentheses. 
FIGURE 2

Final Structural Model

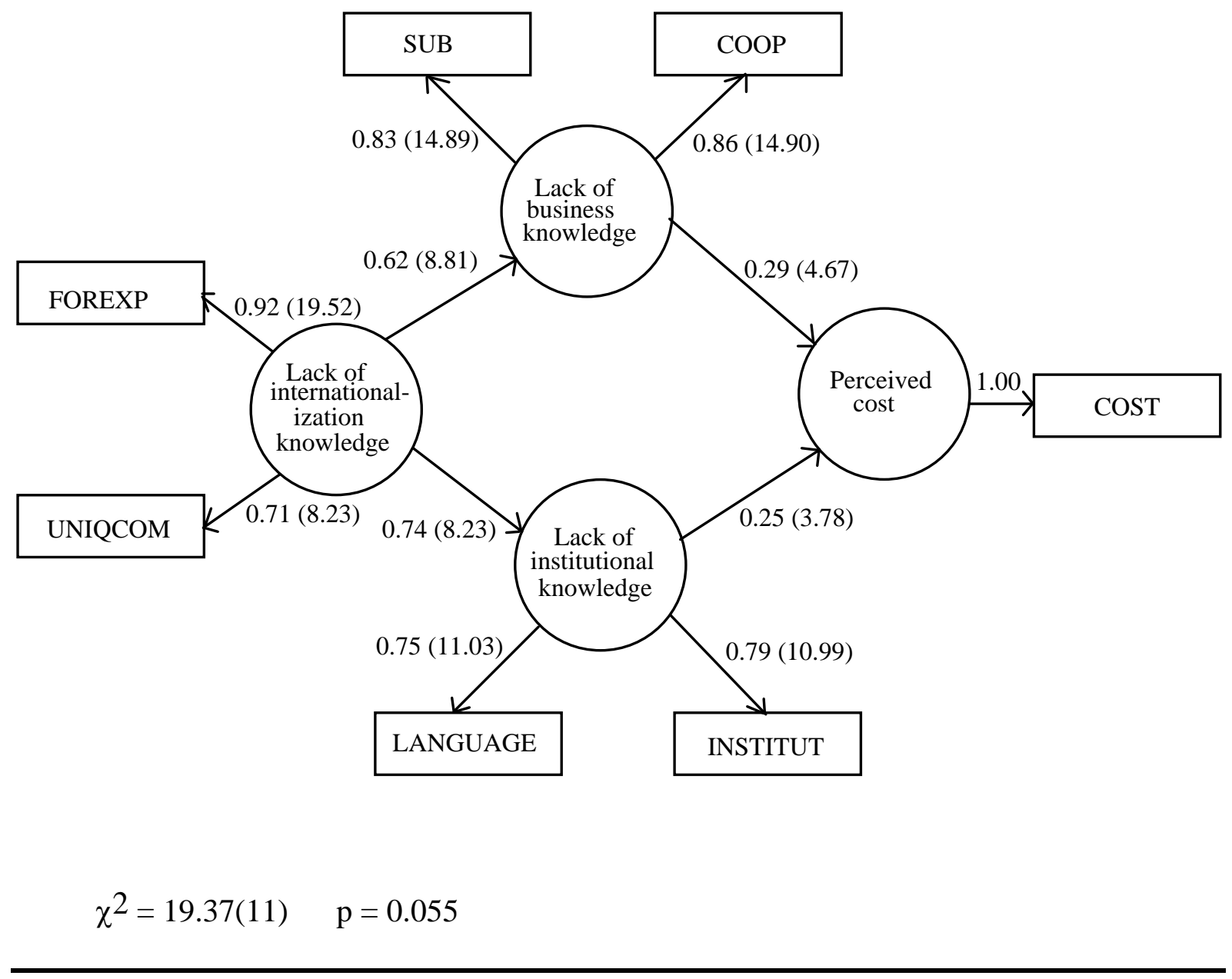

Note: The figures given are factor loadings of causal relations with t-values in parentheses. 


\section{REFERENCES}

Aggarwal, Sanjev \& Sridhar N. Ramaswami. 1992. Choice of foreign market entry: impact of Ownership, location and internationalization factors. Journal of International Business Studies, 23(1): 1-27.

Aharoni, Yair. 1966. The foreign investment decision process. Boston, Mass.: Division of Research, Graduate School of Business Administration, Boston: Harvard University.

Andersen, Otto. 1993. On the internationalization process of firms: A critical analysis. Journal of International Business Studies, 24(2): 209-32.

Anderson, Erin \& Hubert Gatignon. 1986. Modes of entry: A transactions cost analysis and propositions. Journal of International Business Studies, 17(3): 1-26.

Armstrong, J. Scott \& Terry S. Overton. 1977. Estimating non-response bias in mail surveys. Journal of Marketing Research, 14(3): 396-402.

Ayal, Igal \& Jehiel Zif. 1979. Market expansion strategies in multinational marketing. Journal of Marketing, 43(2): 84-94.

Ball, C. A. \& A. E. Tschoegl. 1982. The decision to establish a foreign bank branch or subsidiary: An application of binary classification procedures. Journal of Financial and Quantitative Analysis. 17(September): 411-24

Barkema, Harry G., John H. J. Bell \& Johannes M. Penning. 1996. Foreign entry, cultural barriers, and learning. Strategic Management Journal, 17(2): 151-66.

Beamish, Paul W. 1990. The Internationalization process for smaller Ontario firms: a research agenda. In A. Rugman, editor, Research in global business management, JAI Press, 1:77-92.

\& John C. Banks. 1987. Equity joint ventures and the theory of the multinational enterprises. Journal of International Business Studies, 19(2): 1-16.

\& Jonathan L. Calof. 1989. International business education: A corporation view. Journal of International Business Studies, 20(3): 553-64

Bilkey, Warren J. 1982. Variables associated with export profitability. Journal of International Business Studies, 12(2): 39-55.

\& George Tesar. 1977. The export behaviour of smaller sized Wisconsin manufacturing firms. Journal of International Business Studies, 8(1): 93-98.

Bollen, Kenneth A. 1989. Structural equations with latent variables. New York: John Wiley \& Sons.

\& Scott J. Long. Editors. 1993. Testing structural equation models. Newbury Park: Sage.

Buckley, Peter J. \& Mark Casson. 1976. The future of the multinational enterprise. London: Macmillan.

, Pass, C. L. \& Kate Prescott. 1992. The internationalization of service firms: A comparison with the manufacturing sector. Scandinavian International Business Review, 1(1): 39-56.

Bureau of Industry Economics. 1984. Australian direct investment abroad. Canberra: Australian Government Publishing Service.

Calof, L. Jonathan \& Paul W. Beamish. 1995. Adapting to foreign markets: Explaining internationalization. International Business Review, 4(2):115-31. 
Carlson, Sune. 1974. International transmission of information and the business firm. The Annals of the American Academy of Political and Social Science, 412: 55-63.

Calvet, A. L. 1981. A synthesis of foreign direct investment theories and theories of the multinational firm. Journal of International Business Studies, 12(1): 43-59.

Cavusgil, S. Tamer. 1980. On the internationalization process of firms. European Research, 8(November): 27381.

1984. Organizational Characteristics associated with export activity. Journal of Management Studies, 21(1): 3-22.

Cyert, Richard M. \& James G. March. 1963. A behavioural theory of the firm. New York: Prentice-Hall.

Czinkota, Michael. 1982. Export development strategies: US promotion policies. New York: Praeger Publishers.

Daniels J. D., E. W. Ogram. \& L. M. Radebaugh. 1976. International business: environments and operations. California: Addison-Wesley.

Davidson, William H. 1980. The location of foreign direct investment activity: country characteristics and experience effects. Journal of International Business Studies, 11(2): 9-22.

1983. Market similarity and market selection: Implications of international marketing strategy. Journal

of Business Research, 11: 439-56.

\& Donald G. McFetridge. 1985. Key characteristics in the choice of international technology transfer mode. Journal of International Business Studies, 16(2): 5-21.

Denis, Jean-Emile \& Daniel Depelteau. 1985. Market knowledge, diversification and export expansion. Journal of International Business Studies, 16(3): 77-89.

Dichtl, Erwin, Hans-Georg Koglmayr \& Stefan Mueller. 1990. International orientation as a precondition for export success. Journal of International Business Studies, 21(1): 23-41.

Dunning, John H. 1977. Trade, location of economic activity and the MNE: A search for an eclectic approach.

In B. Ohlin, P. Hesselborn \& M. Wijkman, editors, The international allocation of economic activity. New York: Holmes \& Meier.

1980. Towards an eclectic theory of international production: some empirical tests. Journal of International Business Studies, 11(1): 9-31.

1988. The eclectic paradigm of international production: A restatement and some possible extensions. Journal of International Business Studies, 19(1):1-31.

\& Matthew McQueen. 1983. The eclectic theory of the multinational enterprise and the international

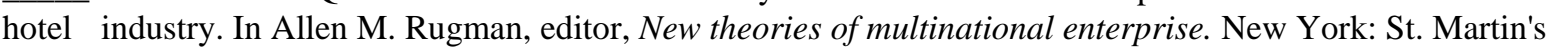

Erramilli, M. Krishna. 1990. Entry mode choice in service industries. International Marketing Review, 7(5): 5062.

1991. The experience factor in foreign market entry behavior of service firms. Journal of International Business Studies, 22(3): 479-501.

\& C. P. Rao. 1990. Choice of foreign market entry mode by service firms. Role of market knowledge. Management International Review, 30(2): 135-50. 
\& C. P. Rao. 1993. Service firms international entry mode choice: A modified transaction-cost analysis approach. Journal of Marketing, 57: 19-38.

Franko, Lawrence G. 1989. Use of minority 50-50 joint ventures by U.S. multinationals during the 1970s: The interaction of host country policies and corporate strategies. Journal of International Business Studies, 20(1): 19-40.

Gatignon, Hubert \& Erin Anderson. 1988. The multinational corporation's degree of control over foreign subsidiaries: An empirical test of a transaction cost explanation. Journal of Law, Economics, and Organization, 4(2): 305-35.

Goodnow, James D. \& James E. H. Hansz. 1972. Environmental determinants of overseas market entry strategies. Journal of International Business Studies, 3(1): 33-50

Green, R. T. \& W. M. Cunningham. 1975. Determinants of U.S. foreign investment: An empirical examination. Management International Review, 15: 113-120.

Grönroos, Christian. 1990. Service management and marketing: Managing the moment of truth in service competition. MA: Lexington Books.

Hayduk, Leslie A. 1987. Structural equation modeling with LISREL: Essentials and advances. Baltimore: John Hopkins University Press.

Hedlund, Gunnar \& Arne Kverneland. 1985. Are entry strategies for foreign markets changing? The case of Swedish investments in Japan. International Studies of Management and Organization, 15(2): 41-59.

Hill, Charles W. L., Peter Hwang \& W. Chan Kim. 1990. An eclectic theory of the choice of international entry mode. Strategic Management Journal, 11(2): 117-28.

Hirsch, Seev. 1993. The globalization of services and service-intensive goods industries. In Y. Aharoni, editor, Coalitions and competition: The globalization of professional business services. 66-78. London: Routledge.

Hofstede, Geert. 1984a. Culture's Consequences: International differences in work related values. Beverly Hills, Calif.: Sage Publications.

1984b. Cultural dimensions in management and planning. Asia Pacific Journal of Management, January: 81-111.

Hörnell, Erik, Jan-Erik Vahlne and Finn Widersheim-Paul. 1972. Export och utlandsetableringar. (Export and foreign establishments). Uppsala: Almqvist \& Wicksell.

Hymer, Stephen H. 1976. The international operations of national firms: A study of direct foreign investment. Cambridge, Mass.: MIT Press.

Jansson, Hans, Mohamed Saqib \& D. Deo Sharma. 1995. The state and transnational corporations: A network approach to industrial policy in India. London: Edward Elgar Publishing.

Johanson, Jan \& Finn Wiedersheim-Paul. 1975. The internationalization of the firm - Four Swedish cases. Journal of Management Studies, 12(3): 305-22.

\& Jan-Erik Vahlne. 1977. The internationalization process of the firm - a model of knowledge development and increasing foreign market commitments. Journal of International Business Studies, 8(1): 23-32.

\& Jan-Erik Vahlne. 1990. The mechanism of internationalisation. The Internationalisation of Business: Theory and Evidence, 7(4): 1-24. 
Jones, E. 1981. Accountancy and the British Economy 1840-1980: The evolution of Ernst \& Whinney, London: Batsford Books.

Jöreskog, Karl-Gustav \& Dag Sörbom. 1993. LISREL 8: Structural equation modelling with the SIMPLIS command language. Chicago: Scientific Software International.

Kilduff, Martin. 1992. Performance and interaction routines in multinational corporations. Journal of International Business Studies, 23(1): 133-45.

1993. The reproduction of inertia in multinational corporations. In S. Ghoshal and D.E Westney, editors, Organization theory and the multinational corporation. 259-274, London: St. Martin's Press.

Kim, W Chan \& Peter Hwang. 1992. Global strategy and multinationals' entry mode choice. Journal of International Business Studies, 23(1): 29-53.

Kindleberger, Charles P. 1969. American business abroad: Six lectures on direct investment. New Haven: Yale University Press.

Kogut, Bruce \& Harbir Singh. 1988. The effect of national culture on the choice of entry mode. Journal of International Business Studies, 19(3): 411-32.

Lenway, Stefanie Ann \& Thomas P. Murtha. 1994. The state as a strategist in international business studies. Journal of International Business Research, (25)3: 513-35.

Levitt, Theodore. 1972. Production-line approach to service. Harvard Business Rewiev, 50(5): 41-52

Lo, T. W. \& A. Yung. 1988. Multinational service firms in centrally-planned economies: Foreign advertising in the PRC, Management International Review, 28(1): 26-32.

Lovelock, Christopher. 1988. Managing services. New Jersey: Prentice-Hall.

Luostarinen, Reijo. 1980. Internationalization of the Firm. Helsinki School of Economics: Helsinki.

Maclayton, D., M. Smith \& J. Hair. 1980. Determinants of foreign market entry: a multivariate analysis of corporate behaviour in the U.S .based health care industry. Management International Review, 20(3): 40-52.

Madhok, Anoop. 1996. Know-how-, Experience- and Competition-related Considerations in Foreign Market Entry: an Exploratory Investigation.. International Business Review, 5(4): 339-366.

1997. Cost, value and foreign market entry mode: The transaction and the firm. Strategic Management Journal, 18(1): 39-61

Makino, Shige \& Andrew Delios. 1996. Local Knowledge Transfer and Performance: Implications for Alliance Formation in Asia. Journal of International Business Studies, 27(5).

March, James G. \& Herbert A. Simon.. 1958. Organizations. New York: Wiley

Millington, A. \& B. Bayliss. 1990. The process of internationalization: UK companies in the E.C. Management International Review, 30(2): 151-61.

Murtha, Thomas P. \& Stefanie Ann Lenway. 1994. Country capabilities and the strategic state: How national political institutions affect multinational corporations' strategies. Strategic Management Journal, 15(Summer): 113-29.

Nelson, Richard R \& Sidney G. Winter. 1982. An evolutionary theory of economic change. Cambridge, MA: Belknap Press. 
Newbould, Gerald D., Peter J. Buckley \& Jane C. Thurwell. 1978. Going international: The experience of smaller companies overseas. New York: John Wiley \& Sons.

Nordström, Kjell. 1990. The internationalization process of the firm: Searching for new patterns and explanations. Ph. D. Dissertation, Stockholm: Institute of International Business Stockholm School of Economics.

Normann, Richard. 1984. Service management. New York: John Wiley.

O’Grady, Shawna \& Henry W. Lane. 1996. The psychic distance paradox. Journal of International Business Studies, 27(2): 309-333.

Penrose, Edith T. 1959. The theory of the growth of the firm. Oxford: Basil Blackwell.

Polanyi. M. 1962. Personal knowledge. London: Routledge \& Kegan Paul.

Quinn, James-Brian \& Christopher E. Gatignon. 1986. Will service follow manufacturing into decline? Harvard Business Review, November-December: 95-103.

Reid, Stan. 1983. Firm internationalization, transaction costs and strategic choice. International Marketing Review, 1(2): 44-56.

12: $141-157$.

Root, Franklin J. 1987. Foreign market entry strategies. New York: AMACON.

Rugman, Allen M. 1981. Inside the multinationals: The economics of internal markets. New York: Columbia University Press.

Sagari, S. B. 1992. United States foreign direct investment in the banking industry. Transnational Corporations, 1(3): 93-123.

Sauvant, Karl P. \& Padma Mallampally. 1993. Transnational corporations in services. London: Routledge.

Seymour, H. 1986. International Investment in the construction industry. Ph. D. Dissertation, Reading, UK.: University of Reading.

Sharma, Deo D. \& Jan Johanson. 1987. Technical consultancy in internationalisation. International Marketing Review, 4(Winter): 20-29.

Shetty, Y. K. 1979. Managing the MNC: European and American styles. Management International Review, 19(3): 39-48.

Simpson, C. 1974. The export decision process: An empirical inquiry. Journal of International Business Studies, 5(1): 107-17.

Stopford, John M. \& Louis T Wells, Jr. 1972. Managing the multinational enterprise. New York: Basic Books. \& S. Strange. 1991. Rival states, rival firms. Cambridge: Cambridge University Press.

Sunzook, F. 1978. How British industry exports, Marketing (UK). June: 29-34.

Terpstra, V. \& C-M. Yu. 1988. Determinants of foreign investment of U.S. advertising agencies. Journal of International Business Studies, 19(1): 33-46. 
United Nations Centre on Transnational Corporations (UNCTC). 1981. Transnational banks: Operations, strategies and their effects on developing countries. New York, United Nations: Sales No. E.81.II.A.7.

Vernon, Raymond. 1966. International investment and international trade in the product cycle. Quarterly Journal of Economics, 80(2): 190-207.

Walter, Ingo. 1985. Barriers to trade in banking and financial services. London: Trade Policy Research Centre.

Weinstein, Arnold K. 1974. The international expansion of U.S. multinationals advertising agencies. MSU Business Topics, 22(Summer): 29-35.

1977. Foreign investment by service firms: The case of multinational advertising agencies. Journal of International Business Studies, 8(1): 83-91.

Wiedersheim-Paul, Finn, H. C. Olson \& L. S. Welch. 1978. Pre-export activity: The first step in internationalization. Journal of International Business Studies, 8(1): 47-58.

Williamson, Oliver E. 1975. Markets and hierarchies: Analysis and antitrust implications. New York: The Free Press.

Winter, Sidney G. 1980. The Institution of capitalism. New York: The Free Press.

Yoffie, David B. 1988. How an industry builds political advantage. Harvard Business Review, May-June: 82-89.

Yu, Chwo-Ming J. 1990. The experience effect and foreign direct investment. Weltwirtschatliches Archiv, 126: 561-79.

Zeithaml, Valerie, A. Parasuraman \& Leonard L Berry. 1985. Problems and strategies in service marketing. Journal of Marketing, 49(2): 33-46. 